DOI https://doi.org/10.32837/app.v0i64.186

УДК 340.115

Цуркан-Сайфуліна Ю. В. * (НУ «ОЮА»)

ORCID ID: https://orcid.org/0000-0003-4926-0850

\title{
ЗВ'ЯЗОК ВЛАДИ І ПРАВА У КОНЦЕПЦІЯХ ЮРИДИЧНОГО ПОЗИТИВІЗМУ
}

\section{CONNECTION BETWEEN POWER AND LAW IN THE FRAMEWORK OF LEGAL POSITIVISM CONCEPTS}

\begin{abstract}
*Yuliia Tsurkan-Saifulina - Doctor of Law, Associate Professor, Head of Political Theories Department, Chernivtsi Institute of Law, National University "Odesa Law Academy" (7, Gregory Skovoroda St., Chernivtsi, Ukraine).
\end{abstract}

\section{Abstract}

The article deals with the essence of the legal understanding and basic approaches to its scientific comprehension. The typology of legal thinking has been identified. The study proposes an approach according to which there are four main types of legal thinking: legal positivism, naturalism, sociological legal thinking, and integrated legal thinking. It is established that each of these types of legal thinking in one way or another deals with the problems of their own conditionality of law.

It is determined that in the simplest form legal positivism is a style of legal thought, which uses three postulates: the postulate on the distinction between law and morality, the postulate on social sources of law and the postulate on the discretion of court decisions. It is proved that the discourse on positivism, which was formed in the post-Soviet space, does not fully correspond to the original positions of modern legal positivism. It has been found that the most relevant problem of the relationship between law and power is the second postulate, which indicates that there is a mandatory institutional link between social and regulatory facts and the content of law.

One of the key methodological foundations of modern legal positivism is justified: the law differs from other regulatory systems not formally but substantively.

It is proved that the most distinct interdependence of the understanding of law and the concept of power is manifested in positivism. Positive understanding 
of law is related to the concept of state power, in which the boundaries of law are outlined by the concept of state power. Law is equal to legislation, and legislation is an institute established by the authorities. A legal vision of law through the notion of legislation is its vision through the lens of the notion of state power that creates the law and ensures its implementation.

It is justified that the purpose of the state is not to create natural human rights (otherwise they would depend on it and would not be inalienable) but in their recognition and maximum protection.

Keywords: law, power, legal understanding, legal positivism, legal coercion, state coercion, instrumental approach.

Праворозуміння - одна з тих фундаментальних проблем філософії права, яка найяскравіше демонструє його належність саме до філософського стилю осмислення правової реальності. Це пов'язано передовсім із тим, що праворозуміння безпосередньо визначає сфери саморефлексії: неможливо сконструювати системне бачення права без постійного звернення до методології та гносеології. Тому слушною уявляється думка О. О. Бандури, що гносеологія права $\epsilon$ не менш рухомою, аніж онтологія, оскільки обидві ці частини правової філософії постійно реконструюються у процесі правового пізнання (Бандура, 2010, с. 31).

Однак, незважаючи на такий фундаментальний статус праворозуміння для формування філософсько-правового дискурсу, вкрай невизначеним залишається його зміст. У літературі використовують інтерпретації праворозуміння як процесу і результату інтелектуальної діяльності щодо осмислення права й формування його ціннісного образу (Алексеев, 1999, с. 212); як відображення у людській свідомості за посередництвом поняття «право» (чи будь-яким іншим рівнозначним з цим словом або символом) того явища, яке оцінюється як корисне для задоволення потреб існування й розвитку певного суб'єкта або ж безпосередньо цих потреб (Рабінович, 2014); як «згустки» правових смислів, які дозволяють інтерпретувати право як самостійний аспект правової реальності (Общетеоретическая юриспруденція, 2011, с. 51) тощо.

Зауважимо, що жоден із наведених варіантів не виглядає переконливим. По-перше, праворозуміння недоцільно розглядати як результат будь-якого осмислення права будь-яким суб'єктом, як це пропонує С. С. Алексєєв, адже тоді незрозуміло, чим праворозуміння відрізняється від правосвідомості. Понад те, це розмиває науковий 
статус праворозуміння, бо виходить, що кожна людина має свій варіант праворозуміння. По-друге, не можна пристати й до потребової концепції П. М. Рабіновича, в якій є кілька недоліків. Саме собою відображення у свідомості не має наслідком формування концепції якогось явища, адже результатом відображення $є$ лише поняття. Понад те, незрозуміло, чому правом іменується лише те, що дозволяє реалізовувати людські потреби. Це сильно звужує поняття права, оскільки часто правові системи містять правила, що якраз обмежують задоволення людських потреб. По-третє, сумнів викликає інтерпретативний варіант сприйняття праворозуміння, адже за такого підходу відбувається розмивання меж праворозуміння. Призмою інтерпретації права можуть виступати й економіка, політика, релігія, мораль, але при цьому немає відповідних типів праворозуміння.

Слушною є думка К. В. Горобця, що «найбільш точним 3 точки зору відображення основних властивостей і функцій праворозуміння в юриспруденції $є$ його розгляд як науково-дослідної програми в тій іiі інтерпретації, яка була запропонована I. Лакатосом. [...] основна відмінність науково-дослідних програм від парадигм полягає в тому, що вони існують синхронно. Це означає, що науково-дослідні програми розвиваються паралельно, конкуруючи між собою у поясненні реальності, яка належить до об'єкта тієї чи іншої науки. Своєю чергою, це не заперечує можливостей революційного розвитку наукового знання: науково-дослідні програми адаптуються до нових принципів наукової раціональності, не відмовляючись при цьому від своїх вихідних ідей та постулатів» (Горобець, 2015, с. 216).

Має значення також проблема типології праворозуміння. Видається недоцільним доволі популярне зведення типів праворозуміння винятково до юснатуралізму та позитивізму (Нерсесянц, 1998), яке вочевидь не відображає всього спектру сформованих науководослідних програм у сфері філософсько-правового осмислення права. Так, пропонується більш розгорнутий варіант типології праворозуміння з його поділом на позитивізм, юснатуралізм, соціологізм та інтегральні концепції (Корунчак, 2011), практикується поділ праворозуміння на донаукове, наукове та постнаукове (Оборотов, 2008, с. 49-55). У деяких сучасних дослідженнях розмежовують класичні типи праворозуміння (юснатуралізм та позитивізм), посткласичні (інтегральне й постмодерністське) (Скоробогатова, 2015). У рамках нашого дослідження буде використовуватися підхід, відповідно до якого існує чотири основних типи праворозуміння: юридичний 
позитивізм, юснатуралізм, соціологічне праворозуміння та інтегральне праворозуміння. Кожен із цих типів праворозуміння так чи інакше торкається проблем владної зумовленості права, тож задача полягає у тому, щоб виявити різні варіанти інтерпретації такого зв'язку й простежити, які методологічні засоби використовуються різними типами праворозуміння для одержання відповідних висновків.

Юридичний позитивізм є найбільш впливовим типом праворозуміння у сучасному світі. Це пояснюється навіть не тим, що він фактично не має альтернатив у рамках англо-американської правової філософії, яка сьогодні задає тон світовому юридичному дискурсу загалом, а й тим, що саме позитивізм найбільш застосовний як до вирішення практичних проблем функціонування правових систем, так і до концептуального осмислення права. При цьому показово, що сам юридичний позитивізм, мабуть, єдиний серед усіх типів праворозуміння, відповідає критеріям наукової раціональності, хоча б тому, що має у своїй структурі внутрішню «опозицію» у вигляді критичних правових досліджень. Характерним є і плюралізм позитивістських течій: виділяють інклюзивний (м'який) та ексклюзивний (жорсткий) позитивізм, нормативізм, неонормативізм тощо (Краевский, 2014).

Перед 3'ясуванням того, як юридичний позитивізм пояснює зв' язок права і влади, слід зупинитися на кількох принципово важливих питаннях. По-перше, має рацію відомий аргентинський філософ права Є. Булигін, коли говорить, що юридичним позитивізмом ні в якому разі не можна називати те, що ним називають на пострадянському просторі. Юридичний позитивізм немає нічого спільного з уявленнями про всесильність закону і про те, що право є продуктом діяльності держави (Булыгин, 2005, с. 7). По-друге, варто розуміти, що юридичний позитивізм у сучасному його потрактовуванні не виправдовує свавільні закони (а іноді висловлюється думка, що він ніколи й не дозволяв цього робити).

У найбільш спрощеному вигляді юридичним позитивізмом вважається стиль правової думки, в якому використовуються два постулати:

(1) постулат про розмежування права $і$ моралі. Він зовсім не означає, як вважає багато вітчизняних авторів, заперечення зв'язку між правом і мораллю: позитивісти його ніколи не заперечували. Історично, культурно, політично тощо мораль і право завжди перебувають у взаємодії. Постулат про розмежування права і моралі вказує на іншу ідею: правова дієвість норм не означає їх моральної дієвості, і навпа- 
ки, те, що норма є морально коректною, не означає, що вона є правовою. По суті, постулат про розмежування права і моралі означає, що між правом і мораллю немає логічного зв'язку, тобто аморальна правова норма діє відповідно до юридичної раціональної логіки, а морально виправдана норма, якщо вона не відображена в тексті законів, не створює жодних юридичних зобов' язань;

(2) постулат про соиіальні джерела права. Відповідно до нього визнається, що існування і зміст права в певному суспільстві залежать від соціальних фактів, тобто від діяльності та вчинків членів цього суспільства (постанов законодавчого органу, результатів голосування, судових рішень, договорів тощо). Це знову суперечить хибному та поширеному уявленню про те, що в юридичному позитивізмі право розглядається як наслідок сваволі влади, коли вона може встановити будь-який закон на власний розсуд. Іноді цей постулат доповнюється деталями, в яких окрім соціальних фактів до уваги беруться також нормативні факти як елементи змісту права (Coleman, 2011).

Як стверджує С. Булигін, а разом із ним й інші сучасні позитивісти (наприклад, Дж. Раз, Дж. Кольман та ін.), ці два постулати виключають існування природного права як частини соціальної реальності, але при цьому абсолютно точно не виключають можливість критики діючого права (Булыгин, 2016, с. 38-42). Це пов' язано із розмежуванням норм і нормативних суджень як важливої методологічної і логічної складової аналітичної юриспруденції (Альчуррон, 2011).

Іноді до цих двох постулатів додають іще один, який, утім, не поділяють усі позитивісти (наприклад, із ним абсолютно не погоджується Г. Кельзен):

(3) постулат про дискретність судових рішень. У випадках, коли право не регулює певну дію, тобто не визначає рішення загального (чи родового) випадку, суддя може вирішити його дискретно, тобто відштовхуючись від власної оцінки ситуації, діючи у такому разі як законодавець. Проблема відсутності одностайності щодо цього постулату пов'язана зі сповідуваною деякими позитивістами тезою про повноту права, відповідно до якої воно не може мати прогалин (Кельзен, 2004). Проблема судової дискреції має особливе значення для юридичного позитивізму, чому присвячено значну кількість досліджень як вітчизняних авторів, так і закордонних юристів (Барак, 2011; Бігун, 2011).

Отже, той дискурс щодо позитивізму, який сформувався загалом на пострадянському просторі, за деякими винятками (Касаткин, 
2013; Максимов, 2000; Оглезнев, 2009), не повною мірою відповідає вихідним позиціям сучасного юридичного позитивізму. Варто також взяти до уваги, що не всі наведені постулати юридичного позитивізму безпосередньо стосуються проблеми співвідношення права i влади, визначення їх зв' язку з позицій формування владного дискурсу права.

Перший постулат торкається значною мірою проблем дійсності і дієвості права, його самостійності чи залежності від моральних імперативів. Ця проблема має здебільшого вихід на питання моральної виправданості права і наслідків відсутності такої виправданості. Варто зауважити, що це питання цікаво вирішується в роботах Дж. Раза, який сформулював ідею самолегітимності права (Касаткин, 2009; Raz, 2009).

Третій постулат, хоча частково і стосується проблем функціонування судової влади, усе ж порушує не владні питання, а проблеми повноти/неповноти права і впливу цього параметру на здійснення судочинства. Сюди ж належать проблеми суддівського активізму. В останні роки в Україні зростає цікавість до цих питань, зокрема, в аспекті інституційного аналізу актів «м' якого» права (Зміївська, 2012).

Отже, найбільш релевантним проблемі зв' язку права і влади є другий постулат, який вказує на обов' язкову наявність інституційного зв' язку між соціальними й нормативними фактами та змістом права. Це зумовлено тим, що момент переходу соціальних і нормативних фактів у правові норми безпосередньо пов'язаний з правотворчістю, яка, як правило, опосередкована політичними інститутами. У цьому контексті варта уваги думка, що в юридичному позитивізмі соціальні й нормативні факти розглядаються як дещо зовнішнє стосовно права, яке, своєю чергою, розглядається як таке, що не має жодного внутрішнього змісту, тобто увесь зміст правових норм уявляється як детермінований соціальним життям і нормативними фактами (Горобець, 2015). Саме це дозволило Г. Радбруху критикувати юридичний позитивізм (до якого він сам свого часу себе зараховував) за релятивізм і відсутність будь-яких спільних для всіх правових систем орієнтирів у правовому розвитку (Радбрух, 2006, С. 5-6).

Однак важливо розуміти, що розгляд питання змісту права за межами власне юридичної логіки часто є єдино можливим варіантом розв'язання тих задач, які постають перед юристами. На це звертає увагу Р. А. Ромашов, коли пише, що позитивізм намагається представити право як щось захищене від суб'єктивізму, як дещо 
інституціоналізоване, і саме це робить його настільки ефективною доктриною: «право як об'єктивна реальність характеризується такими властивостями: 1) існування права не залежить від безпосередньої участі конкретного суб'єкта у процесі правотворчості; 2) дія права не залежить від суб' єктивної оцінки закріплених за допомогою правових норм приписів; 3) реалізація права не залежить від суб'єктивного здійснення чи, навпаки, порушення правових приписів (у першому випадку реалізація права приводить до позитивного результату для правовиконавця, у другому - до юридичної відповідальності правопорушника) (Ромашов, 2007, с. 15).

На зв'язок права і влади у контексті формування змісту права звертає увагу також Ю. М. Оборотов. Він твердить: «багатоаспектність права як явища соціального життя неминуче відбивається на його змісті. Інакше кажучи, зміст права також може бути представлено в різних аспектах, зокрема можуть бути виділені: нормативний аспект (..), ціннісний аспект (...), суб'єктний аспект (..), інформаційний аспект (..), комунікативний аспект (...), поведінковий аспект $(\ldots)$, ідеологічний аспект (...). Зазначений плюралізм змісту права означає, що зміни в змісті права не можуть обмежуватися якимось одним аспектом змісту права. Понад те, зміна одного з аспектів цього змісту ще не означає змін в інших його аспектах. Дисгармонія різних аспектів змісту права призводить до неспроможності механізму дії права, його соціальної неефективності і особистої непотрібності, підміни права іншими соціальними регуляторами суспільних відносин» (Оборотов, 2012).

I дійсно, зміст права визначається не лише нормами, які в ньому містяться, але й тим дискурсом, що детермінує загальну спрямованість правової системи на досягнення іії цілей. До цього дискурсу долучено елементи правової раціональності, а так само вагомі аспекти раціональності політичної, моральної, економічної тощо. Така ситуація зумовлена тим, що з позицій юридичного позитивізму право розглядається передовсім як форма, а питання змісту часто виносяться за межі обговорень.

Слід констатувати, що зміст права, якщо розглядати його як такий, що винесений за рамки власне юридичного дискурсу нормативних систем чи юридичної раціональності, набуває особливого значення в контексті владно детермінованого процесу боротьби за нього. При цьому варто зважити на думку тих дослідників, які стверджують, що боротьба за зміст права не може зводитися до відповідності 
нормативного аспекту змісту права його критеріям, якими розуміється сукупність цінностей та ідеалів, що відображають компромісний інтерес соціуму і відповідають вимогам часу (Толстик, Трусов, 2008, c. 11-12).

Проте доволі неоднозначним і складним з філософсько-правової точки зору є сам зміст тих соціальних і нормативних фактів, які становлять зміст права або претендують на це. Як зауважує В. В. Дудченко, «соціальний факт може стати «нормативним фактом», якщо тільки з початку свого існування був пронизаний позачасовими правовими і моральними цінностями; якщо по своїй суті він $є$ матеріалізацією об'єктивних ідей, які стали соціальними фактами. Ідея справедливості та похідні від неї цінності є ідеями-діями, творчими цінностями, які втілюються в емпіричних фактах» (Дудченко, 2010, с. 214). Соціальна детермінованість права тому визначається суспільними уявленнями про справедливе й правильне - те, що Г. Харт називав «мінімумом природного права у праві позитивному» (Харт, 1998, с. 112).

Сам концепт соціальних фактів пов' язаний з уявленням про соціальну інституціоналізацію в тому сенсі, як їі розуміли класики соціологічного позитивізму Е. Дюркгейм та М. Вебер. Звідси цілком зрозуміло, чому для юридичного позитивізму важливими є питання ціннісної зумовленості права, адже будь-який нормативний факт $є$ втіленням позачасової цінності в чуттєво сприймальному соціальному факті. Така цінність легітимує нормативні факти, а отже, в дієвому визнанні цінності укорінено стрижень права. Справедливо стверджувати, що «нормативні факти» є динамічною концепцією цінностей, концепцією ідей, що проникають у реальну поведінку.

Зрозуміло, що формування нормативних фактів пов'язано значною мірою з владними відносинами, що існують у конкретній спільноті. Власне, момент переходу від соціального факту до нормативного факту опосередковано інститутами політичного характеру. Складно погодитися 3 думкою позитивістів, що право імпліцитно містить у собі цінності, сформовані у соціальному дискурсі. Воно набуває їх у процесі позитивації, тобто надання їм юридичної значущості шляхом парламентської або судової правотворчості (Горобец, 2013, с. 156-158). Утім, очевидно, що правотворчість якраз є точкою перетину політичної і правової раціональності.

Ще на межі XIX-XX ст. сформувалося переконання, що юриспруденція охоплює три основні сфери осмислення права, які по- 
стають як відносно автономні дискурси, кожен з яких побудовано за своєю логікою: історія права, догма права і політика права. Перша сфера стосується минулого права, його витоків та фундаментальних закономірностей розвитку; друга - діючого права, і саме в ній набуває свого втілення прикладна юридична логіка, тобто це та сфера, яка є пріоритетною цариною інтересів юристів; третя ж стосується бажаного права, у ній визначаються основні напрями правотворчості як моменту перетворення політичної раціональності на юридичну логіку. Цю думку висловлювали відомі представники «золотої доби» російської філософії права Ф. В. Тарановський, Є. М. Трубецькой, Г. Ф. Шершеневич (Тарановский, 1923; Трубецкой, 1998; Шершеневич, 1910) та ін. Закономірним наслідком позитивізму та його методології є визнання лише за другою сферою характеру суто юридичного дискурсу в дусі кантіанства (звідси й отримуємо «чисту теорію права» Г. Кельзена, яка відкидає те, що було «до» позитивного права, тобто його історію, і те, що існує поза ним, тобто політику і моральність).

Отже, саме собою питання зв'язку влади і права не є і не може бути пріоритетною сферою інтересів у рамках доктрини юридичного позитивізму, адже соціальна зумовленість правових норм лежить за межами юридичної логіки, а саме - в площині політичної раціональності, тобто це не юридична проблема. Проблема, яка не $є$ юридичною за своїм характером, не може розв'язуватися в рамках методологічної програми юридичного позитивізму. Саме тому для позитивістів складними є питання соціальної справедливості, політичної доцільності, економічної обгрунтованості права тощо, що, своєю чергою, привело до становлення критичних правових досліджень.

Утім, слід повернутися до питання про ціннісну визначеність права, яка завжди перебуває у центрі уваги юридичного позитивізму через свій прямий зв' язок із проблемою нормативних фактів. Про самостійний, позаморальний характер правових цінностей говорив Г. Кельзен, коли стверджував, що правова норма конструює специфічну цінність - правову цінність. Те, що ця правова цінність має відрізнятися від моральної цінності, конструйованої моральною нормою, є, на думку правознавця, лише наслідком позитивної теорії права. Визнання одним із найбільш послідовних позитивістів існування правових цінностей саме собою є фактом показовим. Але тут $є$ чітка логіка, пов' язана з тим, що правові цінності є формальними 
і морально нейтральними, адже, знову ж таки, питання їх змісту виведене за межі юридичного дискурсу. Суб'єктивне право чи юридичний обов' язок не є морально ціннісними чи морально антицінними. Моральну цінність може мати лише якесь конкретне домагання.

Тут набуває принципового значення проблема, хто або що визначає зміст формальних правових цінностей. Для позитивістських інтерпретацій права характерним є підхід, відповідно до якого право є засобом, інструментом, який використовується з тією чи іншою мірою ефективності для вирішення соціальних проблем і досягнення конкретних соиіальних иілей $i$ задоволення певних потреб членів соиіуму. І ця надзвичайно значуща думка є вкрай важливою при характеристиці зв'язку права і влади, адже саме влада, у кінцевому рахунку, має реальну можливість використовувати цей інструмент або ж не використовувати його. Змістовна невизначеність права як постулат юридичного позитивізму надає владі змогу встановлювати той зміст правових норм, який відповідає їі потребам та/чи потребам суспільства.

Формування сучасного філософсько-правового дискурсу нерозривно пов'язане з проблематикою ціннісної визначеності права. 3 одного боку, ця проблематика має зв'язок із глибинними питаннями природи права та характеру його впливу на людину і соціальні спільноти. 3 іншого ж боку, складно ігнорувати той факт, що ціннісна характеристика права обов'язково асоціюється також із примусом - характерною рисою правової реальності, що часто розглядається як основоположна відмінність права від інших соціальних регуляторів.

Інструментальній підхід у правознавстві $є$ доволі поширеним, хоча не можна сказати, що він має глибоко розроблені теоретичні підвалини. Класичні праці С. С. Алексєєва та П. М. Рабіновича, присвячені проблемам інструментального виміру цінності права, сучасні розробки О. В. Малька та В. К. Шундікова дозволяють побачити найбільш перспективні напрями використання інструментального підходу до права. Не менш важливими є також праці Б. Таманаги, Дж. Раза, Д. Ллойда, які демонструють аналітичне бачення права як інструменту.

Ключова ідея інструментального підходу в правознавстві полягає, з одного боку, в представленні права та окремих правових феноменів як засобу досягнення певних цілей, як індивідуальних, так і суспільних (Шундиков, 2014, с. 167-168). Набуває популярності концепція, згідно з якою розгляд права як соціального інструменту дозволяє 
якісніше інтегрувати до юриспруденції такі сучасні методологічні програми як, наприклад, синергетика (Шундиков, 2014а). 3 іншого ж боку, інструментальний підхід має стосунок до правової аксіології, адже, як писав свого часу С. С. Алексєєв, він «дозволяє предметно, конкретизовано розкрити власну цінність права, абсолютність і пріоритет правових начал у суспільстві, силу духу права [...]. Саме 3 позицій інструментального підходу можливо говорити не лише про цінності права взагалі, але й про правові цінності» (Алексеев, 1999 , с. 600).

Інструментальний характер правових цінностей підкреслює також К. В. Горобець, коли пише, що правові цінності $є$ передовсім засобами, які використовуються для досягнення цінностей-цілей. У цьому сенсі жодна правова цінність (правопорядок, законність, суб'єктивні права та юридичні обов'язки тощо) не є самоціллю (Горобец, 2013, c. 80-85).

Відомою інструментальною концепцією правової аксіології є потребовий підхід, розроблюваний П. М. Рабіновичем. У його основі лежить ідея про те, що право є способом організації та структурування соціальних цінностей, а так само - інструментом їх досягнення, захисту, перерозподілу та інформування про них (Рабинович, 2006, с. 26-32). Розвиток цієї ідеї приводить дослідника до формування потребового праворозуміння, відповідно до якого «право - це зумовлені рівнем розвиненості суспільства можливості людини (чи групи людей) отримувати та використовувати засоби, необхідні для задоволення їі біологічно і соціально обгрунтованих - у конкретно-історичних умовах - потреб існування й розвитку і забезпечувані соціальними обов' язками інших суб'єктів» (Рабінович, 2014, с. 17).

Можна продовжувати цей огляд існуючих концепцій і напрямів застосування інструментального підходу в правознавстві, однак його головна ідея у будь-якому разі залишається незмінною. Формально і змістовно право - це (усього лише) інструмент, покликаний виконувати певні функції. Ці функції можуть бути соціально корисними (задоволення потреб людей та соціальних колективів), а можуть бути соціально шкідливими (політичні репресії, переслідування інакодумства тощо). У науковій літературі, утім, широко дискутується питання щодо того, чи може взагалі право бути інструментом досягнення соціально шкідливих цілей. Як видається, історичний досвід неодноразово демонстрував справедливість таких суджень, хоча багато філософів права вважають, що застосування права, 
яке є соціально шкідливим або ж несправедливим, створює стан неправа (формула Радбруха).

Отже, право ставиться у залежність від інших соціальних систем, таких як економіка, політика, мораль, релігія тощо. У цьому виражається одна 3 ключових методологічних засад сучасного юридичного позитивізму: право відрізняється від інших регулятивних систем не змістовно, а формально. Примітною також є думка Дж. Раза, що додатково слід говорити про особливий стиль мислення та аргументації (reasoning), який характеризує відмінні особливості правового дискурсу (Raz, 1999).

Характерною тут є думка К. В. Шундікова, який, підкреслює онтологічну значимість інструменталізму в праві. Він пише, що пошук інституційних властивостей та закономірностей правової матерії є невід'ємною частиною сприйняття правової форми 3 точки зору інструментальної системи (Шундиков, 2014, с. 172). Примітно, що йдеться тут, передовсім, про інституційну систему з точки зору функціонування системи правосуддя, правоохоронної системи та ін. - того, що традиційно охоплюється поняттям «інституційний блок правової системи». Утім, таке бачення проблеми суттєво звужує сферу можливого дискурсу довкола того, чи є право самостійною сферою, адже тоді дискурс виявляється зведеним лише до питань правозастосування i, в небагатьох випадках, - правоінтерпретації. Зі значною мірою певності можна констатувати, що такий підхід так чи інакше характеризує специфіку пострадянського дискурсу про право.

Сьогодні можна констатувати відсутність належного рівня розробки концепції правового примусу як альтернативи державному примусу. Це суттєво підриває релевантність інструментального підходу потребам сучасної юриспруденції. Власне, сам концепт державного примусу часто розглядається крізь призму дискурсу покарання та юридичної відповідальності. Наприклад, М. Й. Байтін у своїй відомій монографії «Сутність права» пише: «у можливості державного примусу як гарантії реалізації, охорони правових норм від порушень полягає одна з найбільш важливих особливостей права» (Байтин, 2001, с. 85). Не можна сказати, що ця позиція є дискутованою чи взагалі ставиться під сумнів у сучасній пострадянській загальнотеоретичній юриспруденції чи філософії права. Варто, утім, зазначити, що сьогодні відбувається поступовий перехід від концепцій державного примусу до концепцій правового примусу. Як пише А. В. Поляков, «підстава суто правового примусу полягає в наявності правомірного 
домагання на виконання правових обов' язків, які у зв' язку з цим мають іманентно примусовий характер» (Поляков, 2003, с. 313). Такий психолого-аксіологічний підхід до розуміння правового примусу явно коріниться у психологічній теорії права Л. Петражицького, хоча і $з$ деякими модифікаціями.

На небезпеку вузького інструментального розуміння права звертає увагу і Б. Таманага. Зокрема, він зазначає: «якщо право - не більше, ніж інструмент примусової сили держави, і якщо ми не можемо дійти згоди щодо розуміння загального блага, тоді ми маємо визнати, що соціальні групи та окремі індивіди намагатимуться збільшити обсяг права для того, щоби забезпечити свої власні потреби та інтереси, або ж орудувати ним як зброєю проти своїх опонентів» (Tamanaha, 2008, р. 7). На думку Б. Таманаги, розуміння права як інструменту, що з'явилося на початку XX ст., було пов'язано з романтизованими уявленнями про його можливості на шляху досягнення певного соціального ідеалу. Сьогодні ж ці ідеї настільки себе дискредитували, що розмови про загальне благо викликають швидше спротив, аніж прийняття.

Американський дослідник пропонує екстраполювати цю проблему на правозастосування, щоби переконатися у тому, які загрози несе для верховенства права інструментальний підхід до права. Він справедливо зазначає, що розгляд права усього лише як інструменту дозволяє винести за межі правової аргументації питання про цілі права та його регулятивну спрямованість. Якщо право є інструментально іррелевантним, то це робить його кон'юнктурним засобом досягнення цілей, що ставить правові ідеї та принципи у залежність від переконань суддів. Він пише: «існуюча загроза верховенству права [...] полягає не в тому, що для судді неможливо бути пов' язаним правилами при винесенні рішень, залишаючи обабіч суб'єктивні переконання. Швидше, загроза йде від bipu у те, що суддя не в змозі цього зробити, та виборі цього не робити» (Tamanaha, 2007, p. 49).

Інструментальний погляд на право, представлений у розрізі правозастосовної системи та концепту примусу, що має зовнішнє стосовно права походження, створює серйозні загрози для верховенства права, оскільки дозволяє знизити значимість ключових правових ідей, які мають принципове значення для правового мислення.

Трохи іншою, хоча й значною мірою контроверсійною, є позиція британського філософа права Л. Гріна, який, розглядаючи інструментальний підхід до права, порушує цілком логічне питання: якщо 
право є лише інструментом, чи означає це, що воно ніколи не є метою? Якщо створення окремих правових норм (законодавчим чи судовим шляхом) може розглядатися як ціль, то виходить, що право як інструмент націлене на саме ж право. Утім, це протиріччя зникає, якщо зайняти позицію, відповідно до якої засіб та мета є відносними, а не абсолютними категоріями. Завдяки цьому встановлення законодавчого регулювання, дійсно, може розглядатися і як ціль, і як засіб, залежно від того, якою є позиція аналізу (Green, 2009). Отже, навіть сприймаючи інструментальне бачення права, можна констатувати його власну цінність як цілі, а не лише як засобу.

Суттєвою проблемою інструментального підходу до права, який грунтується на розробках класичної позитивістської доктрини (передовсім, Г. Кельзена, який першим озвучив думку про право як про «пустий інструмент, зміст якого може бути будь-яким»), є прагнення розглядати право з точки зору феномену, тобто взяте «саме собою». У цьому сенсі «новий» позитивізм, представлений передовсім роботами Г. Харта, дозволяє відкрити нові перспективи розуміння права як сили.

I дійсно, зовсім інакше інструментальний підхід до права розкривається при застосуванні методології, що має в своїй основі аналітичну філософсько-правову традицію. Тут набувають сили поняття правової форми та примусу як значимі аспекти правового дискурсу, який, власне, іє правом. Не вдаючись до дискусій, що зазвичай супроводжують проблематику концептуалізації права в руслі аналітичної філософсько-правової традиції, як трансформуються уявлення про те, в якому сенсі право іменується силою, та як це впливає на релевантність інструментального підходу в правознавстві.

Як уже зазначалось, однією з центральних тез юридичного позитивізму, котрий і є домінуючою науково-дослідною програмою, в рамках якої розвиваються ідеї аналітичної філософії права, є значущість формального критерію відмежування права від усього того, що правом не є. Тут, утім, варто зауважити, що сам феномен правової форми є доволі дискутованим у філософсько-правовій літературі, а так само є невизначеним його статус з точки зору структурування правової реальності. Наприклад, варта уваги думка Ю. Ю. Ветютнєва про те, що соціальна реальність, зокрема правова, має бути відносно активною, діючою, вона не лишає людину байдужою, а примушує рахуватися з собою (Ветютнев, 2013). Додержуючись у цьому аргументі постмодерністських та герменевтичних концепщій, автор також 
пише, що однією з важливих, хоча й далеко не очевидних, властивостей права є його здатність до утворення власного світу, який розуміється у двох сенсах: і як відокремлена жива система, і як вільний від хаосу стан. Це дає йому змогу дійти висновку, що правова форма - це сукупність зовнішніх і внутрішніх властивостей тексту чи дії, що надають останнім юридичного значення (Ветютнев, 2013, с. 16).

Як бачимо, поняття правової форми розуміється тут не в традиційному для вітчизняної загальнотеоретичної юриспруденції ракурсі, де воно зазвичай розкривається з точки зору системи джерел права. Ключовою функцією правової форми, в інтерпретації Ю. Ю. Ветютнєва, є конструювання правової реальності. Інструментальний характер такої правової форми, як уявляється, виражено в ідеї необхідності підпорядкування людей деякому зводу правил, які є рівно застосовними та підкріплюються примусом.

Такий підхід загалом виражає класичну ідею юридичного позитивізму Дж. Остіна щодо існування звички підкорятися велінням суверена. Доти, поки ця звичка зберігається, встановлювані ним правила визнаються правовими. До речі, власне лише концепція Дж. Остіна прямо пов' язує соціальний факт буття права із соціальним фактом існування владних відносин. Право тут розуміється як наказ суверена. Наказ (command) - це веління, підкріплене загрозою покарання/кари на випадок його недотримання. На противагу погрозам грабіжника, такі накази, за Дж. Остіном, мають особливе «джерело» - виходять від суверена, тобто особи (або групи осіб), якій зазвичай/за звичкою підпорядковується більшість членів певного незалежного політичного суспільства і яка зазвичай/за звичкою не підкорюється нікому.

Тому вчений проповідує коректуру (редукцію) мови роздумів про право (відмежування від права тих стандартів, які безпідставно називаються правовими: божественні закони, норми позитивної моралі тощо), а також методологічно зрозуміле, відокремлене від моралі, емпірично (й утилітарно) орієнтоване дослідження/аналіз позитивного права «як воно є»: проект правової науки як «аналітичної юриспруденції» (на противагу «нормативній»/ «критичній» науці про право «яким воно має бути»). Попри те, що Дж. Остін займає важливе і заслужене місце в пантеоні правових мислителів, його концепція в сучасній англо-американській юриспруденції має здебільшого лише історичне значення (Касаткін, 2013).

Фундаментальне уточнення цієї ідеї здійснене Г. Хартом і виражене у фіксації правила визнання як критерію віднесення правил 
до таких, які ми називаємо правовими з огляду на їх застосовність та включення до сфери правової аргументації (Харт, 1998, гл. 5), дало змогу констатувати, що право є силою не лише 3 точки зору можливості застосування примусу, який в контексті вітчизняної традиції юриспруденції нерідко розглядається як дещо зовнішнє стосовно права, але й з позицій конструювання мовного середовища права. Ідеться, передовсім, про те, що примусовість розглядається як характеристика не самого права, а інституційної системи, що його оточує, забезпечує, найперше - інфраструктури правозастосування. Наявність у змісті права санкцій не робить його примусовим автоматично, оскільки санкції мають бути застосовані, а процес застосування права лежить за межею власне права у вузькому сенсі. У цьому ракурсі аналітична філософія права робить поворот до визнання власної сили права як такого, безвідносно до існування міцної та ефективної інституційної системи.

Таке бачення силової характеристики права наводить на думку щодо використання структурної методології Е. Гідденсом, адже він розглядає право саме 3 точки зору структурації соціального буття. Якщо право - це, передовсім, сфера мови, аргументації та смислової детермінації поведінки, то слушною є думка соціолога, що оскільки мова організує мислення і діяльність, у тому сенсі, що привносить у них низку вироблених і зумовлених нормами властивостей, процес його засвоєння встановлює певні межі свідомості та діяльності. Тому структура - це властивість соціальних систем, яка є «замкненою» в практиках, що регулярно відтворюються в часі та простоpi (Гидденс, 2005, с. 248-249).

Для права це означає, найперше, те, що розгляд його як інструменту не позбавляє його сутнісних «силових» характеристик, адже іманентно властива праву мовна структура є примусовою вже на рівні структурування соціальної реальності.

Отже, на рівні мовного аналізу з' ясовується, що право в принципі не може бути беззмістовним, але його зміст визначається інституціоналізованими формами мислення та діяльності, які є центральними складовими правової системи. Тобто за такого підходу фактично констатується субстанційна єдність мислення і діяльності, оскільки вони разом постають як форми комунікації, що є базовими складовими правової реальності. Звідси випливає, що висновок Г. Кельзена, Г. Харта та інших позитивістів про беззмістовність права слід сприймати не як констатацію факту, а як методологічний 
прийом, гіпотезу, що полегшує сприйняття правових феноменів. Примусовий характер права, пов'язаний з його мовним змістом, відповідним способом конструювання соціального життя, не лише не суперечить інструментальному підходу, а є його закономірним логічним продовженням.

Соціальна діяльність у правовій сфері здійснюється у просторі дії права, тобто у соціальному просторі, де існують правові комунікації, а отже - відповідне мовне регламентування мислення та дій людей. Водночас соціальна діяльність у правовій сфері не обмежена лише регламентацією соціальних відносин, оскільки проводяться теоретичні юридичні дослідження, здійснюється доктринальне тлумачення, надаються наукові експертні висновки щодо проектів правових актів та відповідні наукові прогнози тощо, тобто це - наукова правова діяльність, яка грунтується на плюралістичних ідеях.

Таке бачення проблеми сили права, прив' язане до концепції мовного структурування мислення та діяльності, поєднане з інструментальним підходом до форми та змісту права дає змогу констатувати перспективність уточнення тих правових концептів, які виражають дієвість та ефективність правового примусу.

Інструментальний підхід до права як один із найбільш поширених засобів пояснення правової системи в юридичному позитивізмі, безумовно, відкриває суттєві перспективи для осмислення сили права та природи правового примусу. Співвідношення засобу і мети у правовому дискурсі породжує ситуацію, в якій право однозначно зараховують до засобів, а питання про цілі виноситься за межі юридичної аргументації, що криє в собі загрозу для верховенства права. Саме тому використання інструментального підходу має передбачати звернення до надбань аналітичної філософсько-правової традиції, в якій примусовий характер права зумовлюється не лише зовнішніми (формальними) характеристиками правових приписів, а й самим характером юридичної мови та аргументації. Право, виступаючи мовленнєвим інструментом, відповідно конструює соціальну реальність і вже в цьому виявляє свою примусову дію. Тому право $\epsilon$ самостійною силою навіть у ракурсі розгляду його як інструменту (Цуркан-Сайфуліна, 2015).

Отже, найбільш яскраво залежність розуміння права від концепту влади проявляється саме в позитивізмі. Позитивне розуміння права пов' язане з концептом державної влади, в якому межі права окреслено поняттям державної влади. Право - це закон, а закон - це інсти- 
тут, встановлений владою. Юридичне бачення права через поняття закону - це його бачення крізь призму поняття державної влади, яка створює закон і забезпечує його реалізацію.

Держава та іï влада формують своє право як закон, пропонуючи суспільству юридичне бачення світу за допомогою саме цього інструменту. Право в його позитивному розумінні «обтяжене» поняттям державної влади і потрактовується тільки як продукт останньої.

У цьому випадку на шляху юридичного пізнання завжди стоятимуть поняття держави і влади, державної влади. Не випадково класова теорія розглядає право як волю пануючого класу, як його владу, реалізовану в законі. Для того, щоб у законі «розгледіти» право, 3 нього треба зняти «одяг» держави і державної влади, необхідно оголити його. У сфері пізнання шлях до цього тільки один - треба зрозуміти владу, державну владу і саму державу (Хорошильцев, 2015, с. 47).

Відзначимо, що сучасні позитивістські концепції права, які утворюють неопозитивістські школи права - нормативістську (засновник Г. Кельзен) і аналітичну (засновник Г. Харт), у своїх концептуальних положеннях здебільшого спираються на вихідні ідеї класичного позитивізму, а тому вбирають у себе всі його негативні риси. Водночас їм притаманні досягнення, важливі для сучасної юридичної науки і практики.

Так, представники юридичного неопозитивізму підкреслили сильні сторони позитивістських концепцій права, заперечувати наявність яких було б несправедливо, а ігнорувати - нерозумно. Очевидно, що абсолютизація формально визначеного права є небезпечною для суспільства, але за повної відмови від нього нормальне функціонування соціуму є сумнівним.

Отже, нормативно-аналітичне та формально-логічне дослідження права дійсно є корисним. Зрозумілі та чіткі поняття про належну поведінку та засоби захисту ії носіїв, що втілюють норми позитивного права, є тією формальною основою, яка допомагає людині почувати себе впевнено і безпечно. Тому надійність є цінністю права, як і його справедливість.

Але позитивістські та неопозитивістські концепції права потенційно містять у собі можливість неправа, оскільки заперечують справедливість права як його первинну цінність. Для цих концепцій офіційна примусовість правових норм є найвищою цінністю, а така ієрархія цінностей призводить до того, що не людина визнається первинним носієм прав, а держава «дарує» їй природні права (які може і 
відібрати). Таким чином, призначення держави полягає не у створенні природних прав людини (інакше б вони від неї залежали і не були б невід'ємними), а у їх визнанні та максимальному захисті.

Лimepamypa:

Алексеев, С. С. (1999). Право: азбука - теория - философия: опыт комплексного исследования. М.: Статут.

Альчуррон, К. (2011). «Нормативные системы» и другие работы по философии права и логике норм. СПб.: Изд-во Санкт-Петерб. гос. ун-та.

Байтин, М. И. (2001). Сущность права. Современное нормативное правопонимание на грани двух веков. Саратов: СГАП.

Бандура, О. О. (2010). Правознавство у системі наукового знання. Аксіологічно-гносеологічний підхід: монографія. К.: Київ. нац. ун-тет внутр. справ.

Барак, А. (2011). Судейское усмотрение. М.: Норма.

Бігун, В. С. (2011). Філософія правосуддя: ідея та здійснення : монографія.

Булыгин, Е. (2005). К проблеме объективности права. Проблеми фрілософіï права, Т. 1-2, 7-13.

Булыгин, Е. (2016). Избранные работы по теории и философии права. СПб.: Алеф-Пресс.

Ветютнев, Ю. Ю. (2013). Аксиология правовой формы. М.: Юрлитинформ.

Гидденс, Э. (2005). Устроение общества: Очерк теории структурации. 2-е изд. М.: Академический проект.

Горобец, К. В. (2013). Аксиосфера права: философский и юридический дискурс: монографія. О.: Фенікс.

Горобець, К. (2015). Концепт права: спроба системної інтерпретації. Філософія права і загальна теорія права,1-2, 211-223.

Дудченко, В. В. (2010). Роль нормативних фактів у сучасному право розумінні. Право Украӥни, 4, 120-126.

Зміївська, С. С. (2012). Судова практика як джерело формування та розбитку права (загальнотеоретичний аналіз): дис. ... канд. юрид. наук : 12.00.01. Харків.

Касаткин, С. Н. (2009). Философия права Джозефа Раза: моральная (само)легитимация института права и методологический проект 
универсальной теории права. Росийский ежегодник теории права, Вып. 2, 152-157.

Касаткін, С. (2013). Позитивізм в англо-американській філософії права. Вчення Герберта Л. А. Харта. Філософія права і загальна теорія права, 1, 300-313.

Кельзен, Г. (2004). Чисте правознавство. 3 додатком: Проблема справедливості; пер. $з$ нім. О. Мокровольського. К.: Юніверс.

Корунчак, Л. А. (2011). Проблема використання синергетичного підходу при дослідженні правових явищ. Часопис Київського університету права, 3, 58-62.

Краевский, А. А. (2014). Чистое учение о праве Ганса Кельзена и современный юридический позитивизм: дисс. ... кан. юрид. наук : 12.00.01. СПб.

Максимов, С. (2000). Виправдання позитивізму (до аналізу концепції права Х. Харта). Вісник Академії правових наук України, 2, 146-156.

Нерсесянц, В. С. (1998). Юриспруденция. Введение в курс общей теории права и государства. М.: Норма.

Оборотов, Ю. Н. (2008). Разнообразие парадигм правопонимания эпохи постмодерна. Наукові праці Одеської національної юридичної академії, T. VIII, 49-55.

Оборотов, Ю. Н. (2012). Многоаспектность содержания права. Наукові праці Національного університету "Одеська юридична академія», Т. XI, 197-202.

Общетеоретическая юриспрудениия. Учебный курс / под ред. Ю. Н. Оборотова (2011). Одесса: Феникс.

Оглезнев, В. В. (2009). Истоки современной аналитической философии права. Вестник Томского государственного университета. Философия. Соииология. Политология, 4, 81-88.

Поляков, А. В. (2003). Общая теория права: Феноменолого-коммуникативный подход. СПб.: Юридический центр Пресс.

Рабинович, П. (2006). Социалистическое право как изенность.2-е изд., стереотип. Одеса: Юридична література.

Рабінович, П. (2014). Людські потреби - глибинний визначальний чинник право розуміння. Вісник Національної академії правових наук України, 4, 14-24.

Радбрух, Г. (2006). Філософія права; пер. С. Причепій, В. Приходько. К.: Тандем. 
Ромашов, Р. А. (2007). Реалистический позитивизм как интегративный тип современного правопонимания. Університетські наукові записки НаУКМА, 4, 13-20.

Скоробогатов, А. (2015). Праворозуміння: поняття і типологія. Філософія права і загальна теорія права, 1-2, 204-210.

Тарановский, Ф. В. (1923). Эницклопедия права. Берлин: Слово.

Толстик, В. А., Трусов, Н. А. (2008). Борьба за содержание права. Н. Новгород: Нижегород. акад. МВД России.

Трубецкой, Е. Н. (1998). Эницклопедия права. СПб.: Лань.

Харт, Х. Л. А. (1998). Концепція права. К.: Сфера.

Хорошильцев, А. И. (2015). Власть как методологический концепт юридического познания. Провинциальные научные записки, 1, 46-48.

Цуркан-Сайфуліна, Ю. В. (2015). Чи є право самостійною силою? (До інструментального підходу в правознавстві). Вісник Ужгородського національного університету. Серія «Право», Т. 35, 2, 203-206.

Шершеневич, Г. Ф. (1910). Общая теория права. М.: Издательство Бр. Башмаковых. Т. 1.

Шундиков, К. В. (2014). Инструментальный подход и инструментальная теория в современном правоведении: методологический аспект. Ленинградский юридический журнал, 3, 167-175.

Шундиков, К. В. (2014а). Юридический инструментализм в методологии синергетики. Ленинградский юридический журнал, 4, 160-167.

Coleman, J. L. (2011). The Architecture of Jurisprudence. Yale Law Journal, Vol. 121, 2, 2-80.

Green, L. (2009). Law as a Means. University of Oxford Legal Research Paper Series, 8, 1-32.

Raz, J. (1999). Practical reason and norms. Oxford: Oxford University Press.

Raz, J. (2009). The Authority of Law: Essays on Law and Morality. 2nd ed. New York: Oxford University Press.

Tamanaha, B. Z. (2007). How an Instrumental View of Law Corrodes the Rule of Law. DePaul Law Review, Vol. 56, 1-51.

Tamanaha, B. Z. (2008). On the Instrumental View of Law in American Legal Culture. Legal Studies Research Paper Series, Vol. 8, 1-9. 


\section{References:}

Alchurron, K. (2011). «Normativnyye sistemy» i drugiye raboty po filosofii prava $i$ logike norm ["Normative systems" and other works on the philosophy of law and the logic of norms]. St. Petersburg: Izd-vo Sankt-Peterb. gos. un-ta. [in Russian].

Alekseyev, S. S. (1999). Pravo: azbuka - teoriya - filosofiya: opyt kompleksnogo issledovaniya [Law: ABC - Theory - Philosophy: the experience of integrated research]. Moscow: Statut. [in Russian].

Bandura, O. O. (2010). Pravoznavstvo u sy`stemi naukovogo znannya. Aksiologichno-gnoseologichny `j pidxid: monografiya [Jurisprudence in the system of scientific knowledge. Axiological-epistemological approach: monograph]. Kyiv: Ky`yiv. nacz. un-tet vnutr. sprav. [in Ukrainian].

Barak, A. (2011). Sudeyskoye usmotreniye [Judicial discretion]. Moscow: Norma. [in Russian].

Baytin, M. I. (2001). Sushchnost prava. Sovremennoye normativnoye pravoponimaniye na grani dvukh vekov [The essence of law. Modern regulatory understanding on the verge of two centuries]. Saratov: SGAP. [in Russian].

Bigun, V. S. (2011). Filosofiya pravosuddya: ideya ta zdijsnennya: monografiya [Justice philosophy: idea and implementation: monograph]. Kyiv. [in Ukrainian].

Bulygin, E. (2005). K probleme obyektivnosti prava [To the problem of the objectivity of law]. Problemi filosofii prava [Problems of Philosophical Law], T. 1-2, 7-13. [in Russian].

Bulygin, E. (2016). Izbrannyye raboty po teorii $i$ filosofii prava [Selected works on the theory and philosophy of law]. St. Petersburg: Alef-Press. [in Russian].

Coleman, J. L. (2011). The Architecture of Jurisprudence. Yale Law Journal, Vol. 121, 2, 2-80.

Czurkan-Sajfulina, Yu. V. (2015). Chy` ye pravo samostijnoyu sy`loyu? (Do instrumental'nogo pidxodu v pravoznavstvi) [Is the right an independent force? (To the instrumental approach in jurisprudence)]. Visny 'k Uzhgorods 'kogo nacional nogo universy tetu. Seriya «Pravo» [Bulletin of Uzhgorod National University. Law Series], T. 35, 2, 203-206. [in Ukrainian].

Dudchenko, V. V. (2010). Rol` normaty`vny`x faktiv u suchasnomu pravo rozuminni [The role of normative facts in modern law understanding]. Pravo Ukrayiny [Law of Ukraine], 4, 120-126. [in Ukrainian]. 
Giddens, E. (2005). Ustroyeniye obshchestva: Ocherk teorii strukturatsii [Society building: Essay on the theory of structure]. 2-e izd. Moscow: Akademicheskiy proyekt. [in Russian].

Gorobecz', K. (2015). Koncept prava: sproba sy`stemnoyi interpretaciyi [The concept of law: an attempt at systematic interpretation]. Filosofiya prava $i$ zagal na teoriya prava [Philosophy of Law and General Theory of Law], 1-2, 211-223. [in Ukrainian].

Gorobets, K. V. (2013). Aksiosfera prava: filosofskiy i yuridicheskiy diskurs: monografiya [Axiosphere of Law: Philosophical and Legal Discourse: Monograph]. Odesa: Feniks. [in Russian].

Green, L. (2009). Law as a Means. University of Oxford Legal Research Paper Series, 8, 1-32.

Kasatkin, S. (2013). Pozy`ty`vizm v anglo-amery`kans`kij filosofiyi prava. Vchennya Gerberta L. A. Xarta [Positivism in the Anglo-American Philosophy of Law. The teachings of Herbert LA Hart]. Filosofiya prava $i$ zagal na teoriya prava [Philosophy of Law and General Theory of Law], 1, 300-313. [in Ukrainian].

Kasatkin, S. N. (2009). Filosofiya prava Dzhozefa Raza: moralnaya (samo) legitimatsiya instituta prava i metodologicheskiy proyekt universalnoy teorii prava [The philosophy of law of Joseph Raz: the moral (self) legitimation of the institution of law and the methodological project of a universal theory of law]. Rosiyskiy ezhegodnik teorii prava [Russian Yearbook of Theory of Law], Vyp. 2, 152-157. [in Russian].

Kel`zen, G. (2004). Chy`ste pravoznavstvo. Z dodatkom: Problema spravedly 'vosti; per. z nim. O. Mokrovol's` kogo [Pure jurisprudence. With the Appendix: The Problem of Justice; trans. with him. O. Mokrovsky]. Kyiv: Yunivers. [in Ukrainian].

Khoroshiltsev, A. I. (2015). Vlast kak metodologicheskiy kontsept yuridicheskogo poznaniya [Power as a methodological concept of legal knowledge]. Provintsialnyye nauchnyye zapiski [Provincial Scientific Notes], 1, 46-48. [in Russian].

Korunchak, L. A. (2011). Problema vy`kory`stannya sy`nergety`chnogo pidxodu pry` doslidzhenni pravovy`x yavy`shh [The problem of using a synergistic approach in the study of legal phenomena]. Chasopy's Ky 'yivs 'kogo universy 'tetu prava [Journal of the Kiev University of Law], 3, 58-62. [in Ukrainian].

Krayevskiy, A. A. (2014). Chistoye ucheniye o prave Gansa Kelzena i sovremennyy yuridicheskiy pozitivizm: diss. ... kan. yurid. nauk: 12.00.01 
[Pure doctrine of the law of Hans Kelsen and modern legal positivism: Diss. ... can legal Sciences: 12.00.01]. St. Petersburg. [in Russian].

Maksy`mov, S. (2000). Vy`pravdannya pozy`ty`vizmu (do analizu koncepciyi prava X. Xarta) [The justification of positivism (before the analysis of H. Hart's concept of law)]. Visny'k Akademiyi pravovy 'x nauk Ukrayiny [Bulletin of the Academy of Legal Sciences of Ukraine], 2, 146-156. [in Ukrainian].

Nersesyants, V.S. (1998). Yurisprudentsiya. Vvedeniye v kurs obshchey teorii prava i gosudarstva [Law. Introduction to the course of the general theory of law and the state]. Moscow: Norma. [in Russian].

Oborotov, Yu. N. (2008). Raznoobraziye paradigm pravoponimaniya epokhi postmoderna [A variety of paradigms of legal understanding of the postmodern era]. Naukovi praci Odes 'koyi nacional noyi yury'dy'chnoyi akademiyi [Scientific works of the Odessa National Law Academy], T. VIII, 49-55. [in Russian].

Oborotov, Yu. N. (2012). Mnogoaspektnost soderzhaniya prava [The multidimensional nature of the content of law]. Naukovi praci Nacional nogo universy 'tetu "Odes 'ka yury`dy 'chna akademiya» [Scientific works of the National University “Odessa Law Academy"], T. XI, 197-202. [in Russian].

Obshcheteoreticheskaya yurisprudentsiya. Uchebnyy kurs / pod red. Yu. N. Oborotova (2011) [General theoretical jurisprudence. Training course / ed. Yu.N. Oborotova]. Odesa: Feniks. [in Russian].

Ogleznev, V. V. (2009). Istoki sovremennoy analiticheskoy filosofii prava [The origins of modern analytical philosophy of law]. Vestnik Tomskogo gosudarstvennogo universiteta. Filosofiya. Sotsiologiya. Politologiya [Bulletin of Tomsk State University. Philosophy. Sociology. Political Science], 4, 81-88. [in Russian].

Polyakov, A. V. (2003). Obshchaya teoriya prava: Fenomenologokommunikationyy podkhod [General theory of law: Phenomenologicalcommunicative approach]. St. Petersburg: Yuridicheskiy tsentr Press. [in Russian].

Rabinovich, P. (2006). Sotsialisticheskoye pravo kak tsennost [Socialist law as a value]. 2-e izd., stereotip. Odesa: Yuridichna literatura. [in Russian].

Rabinovy`ch, P. (2014). Lyuds`ki potreby` - gly`by`nny`j vy`znachal`ny`j chy`nny`k pravo rozuminnya [Human needs are a profound determinant of the right to understand]. Visny 'k Nacional noyi akademiyi pravovy' $x$ nauk 
Ukrayiny [Bulletin of the National Academy of Law Sciences of Ukraine], 4, 14-24. [in Ukrainian].

Radbrux, G`. (2006). Filosofiya prava; per. Ye. Pry`chepij, V. Pry`xod`ko [Philosophy of Law; trans. E. Trailer, V. Prikhodko]. Kyiv: Tandem. [in Ukrainian].

Raz, J. (1999). Practical reason and norms. Oxford: Oxford University Press.

Raz, J. (2009). The Authority of Law: Essays on Law and Morality. 2nd ed. New York: Oxford University Press.

Romashov, R. A. (2007). Realisticheskiy pozitivizm kak integrativnyy tip sovremennogo pravoponimaniya [Realistic positivism as an integrative type of modern legal understanding]. Universitetski naukovi zapiski NaUKMA [Universities of science notes of NaUKMA], 4, 13-20. [in Russian].

Shershenevich, G. F. (1910). Obshchaya teoriya prava [General theory of law]. Moscow: Izdatelstvo Br. Bashmakovykh. T. 1. [in Russian].

Shundikov, K. V. (2014). Instrumentalnyy podkhod i instrumentalnaya teoriya $\mathrm{v}$ sovremennom pravovedenii: metodologicheskiy aspekt [The instrumental approach and instrumental theory in modern jurisprudence: methodological aspect]. Leningradskiy yuridicheskiy zhurnal [Leningrad Journal of Law], 3, 167-175. [in Russian].

Shundikov, K. V. (2014a). Yuridicheskiy instrumentalizm v metodologii sinergetiki [Legal instrumentalism in the methodology of synergetics]. Leningradskiy yuridicheskiy zhurnal [Leningrad Law Journal], 4, 160-167. [in Russian].

Skorobogatov, A. (2015). Pravorozuminnya: ponyattya i ty`pologiya [Orthodoxy: concept and typology]. Filosofiya prava $i$ zagal na teoriya prava [Philosophy of Law and General Theory of Law], 1-2, 204-210. [in Ukrainian].

Tamanaha, B. Z. (2007). How an Instrumental View of Law Corrodes the Rule of Law. DePaul Law Review, Vol. 56, 1-51.

Tamanaha, B. Z. (2008). On the Instrumental View of Law in American Legal Culture. Legal Studies Research Paper Series, Vol. 8, 1-9.

Taranovskiy, F. V. (1923). Entsiklopediya prava [Encyclopedia of Law]. Berlin: Slovo. [in Russian].

Tolstik, V. A., Trusov, N. A. (2008). Borba za soderzhaniye prava [The struggle for the content of law]. N. Novgorod: Nizhegorod. akad. MVD Rossii. [in Russian]. 
Trubetskoy, E. N. (1998). Entsiklopediya prava [Encyclopedia of Law]. St. Petersburg: Lan. [in Russian].

Vetyutnev, Yu. Yu. (2013). Aksiologiya pravovoy formy [Axiology of legal form]. Moscow: Yurlitinform. [in Russian].

Xart, X. L. A. (1998). Koncepciya prava [Concept of law]. Kyiv: Sfera. [in Ukrainian].

Zmiyivs`ka, S. S. (2012). Sudova prakty `ka yak dzherelo formuvannya ta rozvy'tku prava (zagal noteorety'chny'j analiz): dy's. ... kand. yury'd. nauk: 12.00.01 [Court practice as a source of law formation and development (theoretical analysis): diss. ... Cand. lawyer. Sciences: 12.00.01]. Kharkiv. [in Ukrainian].

\section{Анотація}

Цуркан-Сайфуліна Ю. В. З6'язок влади і права у концепиіях юридичного позитивізму. - Стаття.

В статті розглянуто сутність право розуміння та основні підходи иоого наукового осмислення. Визначено типологію праворозуміння. У рамках дослідження запропоновано підхід, вidnовідно до якого існує чотири основних типи праворозуміння: юридичний позитивізм, юснатуралізм, соиіологічне праворозуміння та інтегральне праворозуміння. Встановлено, щуо кожен із изих типів праворозуміння так чи інакше торкається проблем владної зумовленості права.

Визначено, що у найбільш спрощеному вигляді юридичним позитивізмом вважається стиль правової думки, в якому використовуються три постулати: постулат про розмежування права $i$ моралі, постулат про соціальні джерела права та постулат про дискретність судових ріменъ. Доведено, що той дискурс щзодо позитивізму, який сфрормувався на пострадянському просторі, не повною мірою відповідає вихідним позиціям сучасного юридичного позитивізму. 3'ясовано, щуо найбільш релевантним проблемі зв'язку права і влади є другий постулат, який Вказує на обов'язкову наявність інституиійного зв'язку між соціальними й нормативними фактами та змістом права.

Обгрунтовано одну з ключових методологічних засад сучасного юридичного позитивізму: право відрізняеться від інших регулятивних систем не змістовно, а формально.

Доведено, щзо найбільш яскраво залежність розуміння права від концепту влади проявляється саме $b$ позитивізмі. Позитивне розуміння права пов'язане з кониептом державної влади, в якому межі права окреслено 
поняттам державної влади. Право - цее закон, а закон - ије інститут, встановлений Владою. Юридичне бачення права через поняття закону - иее його бачення крізь призму поняття державної влади, яка створюе закон $i$ забезпечує його реалізацію.

Обгрунтовано, що призначення держави полягає не у створенні природних прав ююдини (інакше б вони від неї залежали і не були б невід'ємними), а у їх визнанні та максимальному захисті.

Ключові слова: право, влада, праворозуміння, юридичний позитивізм, правовий примус, державний примус, інструментальний підхід. 